\section{Respiratory Metabolism of Aerated Potato Disks}

Research in several laboratories has clearly demonstrated that aerated potato disks develop an inoreased capacity for uptake of oxygen ${ }^{1-7}$. This additional respiratory capacity is not increased by 2,4-dinitrophenol ${ }^{7}$ and is relatively insensitive to inhibition by cyanide ${ }^{6}$ and carbon monoxide ${ }^{5,6}$. How ever, cyanide ${ }^{8}$, low temparature $\left(0-5^{\circ} \mathrm{C} .\right)^{7}$ or absence of oxygen at normal temperature ${ }^{8}$ will prevent the development of the increased respiratory capacity.

In view of these observations, it became of interest to us to learn whether the development of increased respiratory capacity requires the synthesis of new protein and whether the increased oxygen uptake is coupled to phosphorylation to give an increased work capacity. In our experiments (Table 1) the presence of the protein synthesis inhibitor, chloramphenicol, during the 24-hr. aeration of the potato disks prevented increase in respiratory capacity. Because the presence of chloramphenicol during the measurement of uptake of oxygen has little effect on the respiration of either fresh or aerated disks, it can be concluded that protein synthesis is a necessary part of the development of an increased capacity for uptake of oxygen.

Table 1. THE HFFECT ON CHLORAMPHENICOL ON THK DEVELOPMENT OF AN INCREASED ReSPIRATORY CaPaCITY BY AFRAThD POTATO DISKS. Oxygen uptake $\left(\mu \mathrm{l} . \mathrm{O}_{2} / 500 \mathrm{mgm}\right.$./hr. $)$

\begin{tabular}{|c|c|c|c|c|c|}
\hline $\begin{array}{c}\text { Fresh } \\
\text { control }\end{array}$ & $\begin{array}{c}\text { Gresh }+ \\
\text { chloram- } \\
\text { phenicol }\end{array}$ & $\begin{array}{c}\text { Inhibition } \\
\text { (per cent) }\end{array}$ & $\begin{array}{c}\text { Aerated } \\
\text { in the } \\
\text { presence of } \\
\text { chlorated } \\
\text { control } \\
\text { 1henicol* }\end{array}$ & $\begin{array}{c}\text { Inhibition } \\
\text { (per cent) }\end{array}$ \\
\hline 24 & 19 & 25 & 105 & 33 & $6 !$ \\
24 & 25 & -4 & 50 & 16 & 68 \\
32 & 29 & 4 & 101 & 55 & 46 \\
\hline Av. 27 & 24 & 10 & 85 & 35 & 61 \\
\hline
\end{tabular}

* Potato disks were aerated in the presence of $1 \mathrm{mgm} . / \mathrm{ml}$. chloramphenicol for $24 \mathrm{hr}$.

Each Warburg flask contained : $0.01 M$ phosphate, $p$ H $6.9,500$ mgm. potato disks $(1 \mathrm{~cm} . \times 1 \mathrm{~mm}), 3 \times 10^{-4} M$ hydrogen cyanide $\mathrm{mgm} . / \mathrm{ml}$. chloramphenicol, 20 per cent potassium hydroxide in the centre well. Incubation temperature, $30^{\circ} \mathrm{C}$.

The phosphorylative capacity of the potato disks was measured by determining the extent of incorporation of phosphorus-32 into organic phosphate esters during the measurement of uptake of oxygen. Results obtained in this way indicate that the increment of respiratory capacity is coupled to phosphorylation (Table 2). The incorporation of phosphorus-32 into the aerated disks is not as sensitive to inhibition by cyanide as that of fresh disks. However, the phosphorylation of aerated disks is in-

Table 2. HFFet of Cyanide on thi phosphorylation Capacity FF FRS AND AERAT ED POTATO D.SKS

Incorporation of phosphorus-32 into organic esters. (Per cent of

\begin{tabular}{|c|c|c|c|c|c|}
\hline $\begin{array}{c}\text { Fresh } \\
\text { control }\end{array}$ & $\begin{array}{c}\text { Fresh } \\
\text { HCN }\end{array}$ & $\begin{array}{c}\text { Inhibition } \\
\text { (per cent) }\end{array}$ & $\begin{array}{c}\text { Aerated } \\
\text { control }\end{array}$ & $\begin{array}{c}\text { Aerated } \\
\text { +HCN }\end{array}$ & $\begin{array}{c}\text { Inhibition } \\
\text { (per cent) }\end{array}$ \\
\hline $32 \cdot 6$ & $13 \cdot 7$ & 58 & $23 \cdot 6$ & $30 \cdot 1$ & $-27 \cdot 5$ \\
$12 \cdot 6$ & $4 \cdot 2$ & 67 & $27 \cdot 6$ & $24 \cdot 5$ & $11 \cdot 2$ \\
23.9 & $8 \cdot 1$ & 66 & $32 \cdot 7$ & $25 \cdot 6$ & $21 \cdot 7$ \\
- & - & - & $23 \cdot 5$ & $18 \cdot 3$ & 22.1 \\
\hline Av. 23.0 & - & - & $19 \cdot 9$ & $25 \cdot 0$ & $-25 \cdot 6$ \\
\hline
\end{tabular}

Incubation with phosphorus-32 was conducted in a Warburg flask during measurements of oxygen uptake. The flasks contained $0.01 \mathrm{M}$ phosphate buffer, $500 \mathrm{mgm}$. (fresh weight potato disks), $3 \times 10^{-4}$ hydrogen cyanide and 20 per cent potass hibited by the same levels of dinitrophenol required to inhibit the phosphorylation of fresh disks.

These results lead us to the conclusion that the increased respiration of aerated potato disks is mediated by enzymes which are synthesized during the aeration period. Further, it appears that this additional electron transport to oxygen is coupled to phosphorylation because the phosphorylation observed in a fixed incubation time is not sensitive to a level of cyanide sufficient to inhibit 64 per cent of the phosphorylation of fresh disks. If the additional respiration were not coupled to phosphoryla. tion, then the phosphorylation after $24-\mathrm{hr}$. eeration should still be sensitive to cyanide inhibition.

The results reported here can be accounted for by the hypothesis that eytochrome oxidase is a limiting factor in the respiration of fresh potato disks; and that on aeration, there is a net synthesis of an excess of cytochrome oxidase so that this cyanide-sensitive step is no longer limiting.

\section{Nona Calo \\ JoY Marks \\ J. E. VARNEK}

Dept. of Agricultural Biochernistry,

Ohio State University, Columbus 10.

Buetiu, J., Bot. Z., 45, $6 \pi 1$ (1887).

" Richards, H. M., Ann. Bot., 10, 531 (1846).

${ }^{3}$ Lutman, B. F., Bull. Torrey Bot. Club, 53, 429 (1926).

* Steward, F. C., Protoplasma, 15, 497 (1931).

- schade, A., and Levy, H., Arch. Biochem., 20, 211 (1949).

- Thiman, K., Yocum, C. S., and Hackett, D. P., Arch. Biochem. Biophys., 53, 249 (1954).

' Sharpensteen, Helen, Ph.D. Dissertation, 1953, Univ. of Michigan. ${ }^{8}$ Hackett, D. P., Proc. Ann. Soc. Plant Physiol., 31, xl (1956).

\section{Ion Permeability of the Plasmalemma of the Plant Cell}

WALKER ${ }^{\perp}$ has suggested that for Nitella there is evidence for a layer on the outside of the cytoplasm, a plasmalemma, which offers considerable resistance to the passage of ions. In support of this suggestion he advances two pieces of evidence-the bulk of the high d.c. resistance across the eytoplasmic layer from vacuole to outside solution of chloride lies in the cytoplasm and not in the tonoplast, and secondly, that the equilibrium concentration of calcium ions in the cytoplasm calculated from the potential difference is absurdly high.

If the tonoplast is practically impermeable to cations, then the conductivity of the cytoplasm and tonoplast will depend on the concentration and mobility of anions in these phases. If they are similar for both phases, then the bulk of the resistance will reside in the cytoplasm because of its much greater thickness. The average resistance of $6,000 \mathrm{ohm}$ sq. $\mathrm{cm}$. with a thickness of $10 \mu$ would be appropriate for a concentration of chlorine ion in the cytoplasm of $2 \cdot 6 \mu$ equiv./l. This is the equilibrium concentration if the external solution has a concentration of $1.5 \mathrm{~m}$.equiv./l. and a potential difference relative: to the cytoplasm of $160 \mathrm{mV}$. If the external cation were univalent then the concentration of nondiffusible anion would be 0.87 equiv./1. The external concentration and that of non-diffusible anion would be smaller if the potential difference were less. The concentrations used ranged from 0.05 to 1.0 m.equiv., but the values for the potential difference with these solutions are not given. 